UDC 316.334:658.8

http://doi.org/10.21272/mmi.2019.2-02

JEL Classification: L31, M31

Volkan Goktas,

Sakarya University, Turkey

Emre Erol,

Sakarya University, Turkey

Remzi Altunisik,

Ph.D., Professor, Sakarya University, Turkey

Kadir Ardic,

Ph.D., Professor, Sakarya University, Turkey

\title{
SOCIAL MARKETING IN CHARITABLE GIVING INTENTIONS: A SERIAL MEDIATION MODEL
}

Abstract. Charitable organizations play a significant role in today's society that cannot be achieved by governments or businesses. They have missions ranging from providing hot soup to victims after an earthquake to providing shelters to refugees running away from the war. However, in order to achieve these missions, they need the support of individuals in terms of monetary and time donations (voluntary work). Charitable organizations act as intermediaries and they transmit the sources from the wealthy people who want to help the needy. The importance of individual giving for charitable organizations attracted the research in the marketing field and authors examined the role of attitudes and perceptions. A range of attitudinal and perceptual factors can influence individuals' charitable giving intention including attitudes toward charitable organizations, attitudes toward helping others, and trust in the third sector. The prior studies have demonstrated that these variables were interrelated. However, they examined the relationship between these variables and charitable giving intention independently and it is still unclear how these perceptual and attitudinal variables are associated with each other and charitable giving intention. To fill this research gap, the purpose of this study is to test the serial mediating role of attitudes toward charitable organizations and trust in the third sector in the relationship between attitudes toward helping others and charitable giving intention. We, therefore, built a serial mediation model showing the relationship between the variables and tested it with the data obtained from a convenience sample of 417 respondents who live in the Eastern Marmara Region, Turkey. Our findings show that attitudes toward helping others have a positive indirect effect on both intended to give time and intention to give money through attitudes toward charitable organizations and trust in the third sector in sequence. Additionally, attitudes toward charitable organizations have a positive specific indirect effect on the intention to give time and intention to give money in sequence through trust in the third sector. Also, trust in the third sector has a positive direct effect on the intention to give time and intention to give money. These findings indicate that attitudes toward charitable organizations and trust in the third sector sequentially mediate the relationship between intention to give time and intention to give money. The results also suggest that the proposed model explains almost $35 \%$ of the variance in intention to give money and $11 \%$ of the variance in intention to time.

Keywords: attitudes, charitable organizations, charitable giving, intention, philanthropy, trust, third sector.

Introduction. The number of charitable organizations (COs) around the world has grown rapidly in the last thirty years due to the increase in diseases, environmental issues, dire economic conditions and armed conflicts (Sargeant, 2009; Pacesila and Ciocoiu, 2017). In line with the global trend, the Turkish charity sector is one of the fastest growing sectors in the country with currently almost 117000 active COs. This is almost as twice as it was in 2000 and now more people in the society can benefit from the activities of these organizations compared to the past (T.R. Ministry of Interior Department of Association, 2019). The size of a donation and the number of donors have also increased. In 2014, it was estimated that the total amount of monetary donations made by individuals reached 13.7 billion Turkish Liras (TUSEV, 2016a), which was worth $0,8 \%$ of Turkish GDP. It would have enabled Turkey to enter the «most generous countries» list which was prepared on the basis of percentage of GDP

Cite as: Goktas, V., Erol, E., Altunisik, R., \& Ardic, K. (2019). Social Marketing in Charitable Giving Intentions: a Serial Mediation Model. Marketing and Management of Innovations, 2, 21-32. http://doi.org/10.21272/mmi.2019.2-02 
donated to COs by individual donors (CAF, 2016) although a more recent research done by CAF (2018) indicated that Turkish individuals are not likely to donate their time or money to people in need using Cos. In addition to these positive developments, there are also negative issues to highlight. For instance, the charity sector has lost trustworthiness and the number of people who want to donate to COs decreased in many countries. According to an extensive study (CAF, 2018) in which 12000 people living in the United Kingdom participated, the number of people who donated to charities decreased significantly. Additionally, in line with the findings of the study conducted two years earlier CAF (2016) again only $50 \%$ of the participants agreed that charities were trustworthy. According to another study conducted by Ipsos MORI (2016), 33\% of the respondents reported that their trust and confidence in the charitable sector decreased over the past two years. The sector has a similar problem in Turkey. According to TUSEV (2016b), almost $90 \%$ of the individuals reported that they intended to help the needy without using an intermediary organization while lack of trust was the most frequently reported third sector related factor of this choice. Of course, the problems that COs face, are not limited to the negative perception. The increasing number of organizations in the sector has led to much tougher competition. This tense competition has attracted the researchers to examine further factors influencing people's motivation to donate. Despite huge interest in the motivational factors, there are noticeable gaps in the literature. In the past, most studies in the literature focused heavily on the influence of intrinsic motivational factors (e.g. altruism, empathy, sympathy) in the donation and paid little attention to the role of organizational factors such as trust in the third sector (TIS). Most importantly, since most of the prior studies examined the influence of internal and organizational factors on charitable giving intention (CGI) independently, the mechanism among the CGI, internal motivational factors and organizational factors is not clear. Specifically, the prior research treated charitable giving as a process which is free from a possible intervening role of organization related factors such as ACO (e.g. Banks and Raciti, 2018). Furthermore, the support given to COs by individuals is not limited to the monetary donations. People can also spend their time on COs' activities. In order to fill these gaps in the field, this study explores potential intervening variables attitudes toward helping others (AHO) and TIS which could mediate the relationship between $\mathrm{AHO}$ and $\mathrm{CGI}$. In comparison to many prior studies in the related field, this study focuses not only on monetary donations but also on the intention to work for charity. The findings of this study provide an insight into the understanding of individual charitable giving.

Literature Review. The first variable that the current study focuses on is individual charitable giving intention which is a behavioural intention regarding prosocial behaviour. Prosocial behaviour is any behaviour that benefits others (Hinde and Groebel, 1991: 5). So, giving money to a beggar, giving seats to elderly in the bus or helping a person who has an accident are all accepted as prosocial behaviours. Charitable giving is also another way of prosocial behaviour and it is different from a simple helping behaviour since it involves allocating of resources while helping involves exertion (Yang et al., 2015: 3). Therefore, to treat behaviour as charitable giving, an individual should spend his/her time or money for the goodness of the beneficiaries of $\mathrm{COs}$. Both donating time and money produce an outcome that is related to the prosocial act, but these two actions differ from each other. Specifically, donation of time does not directly result in monetary outcomes unlike donation of money (Kandaurova and Lee, 2018: 2). Another concept in the variable is the behavioural intention. «Behavioural intentions are instructions that people give to themselves to behave in certain ways» (Triandis, 1980: 203) and they may be antecedents of individual behaviour (e.g. Warshaw and Davis, 1984). After expressing the terms "charitable giving» and «behavioural intention», charitable giving can be defined as a self-instruction that individuals give themselves to make a monetary or time donation to a $\mathrm{CO}$.

The second variable regarding the study is attitudes toward helping others. The question of «why do people help?» has long been an elusive research topic for social scientists (e.g. Janus and Misiorek, 2018) and research trying to answer this question focused heavily on motivational factors which are 
related to four theories; empathy-altruism hypotheses (Batson et al., 1991), social exchange theory (Blau, 1964), negative state relief (Cialdini et al., 1973), and empathic-joy hypothesis (Smith et al., 1989). According to social exchange theory, individuals help each other because they expect both intangible and tangible benefits in return (Matenge, 2015:4). Empathy-altruism hypothesis suggests that empathetic concern evokes the altruistic behaviour and people help for altruistic reasons (Verhaert and Poel, 2011: 1289). On the other hand, negative state relief theory suggests that people help in order to decrease the pain they see someone suffering (Cialdini et al., 1973). According to the empathic-joy hypothesis, people help because they like the positive feelings they have after helping. To summarize, people are motivated to help by selfish or other oriented motives and these motives can play an important role in the individual giving process. Along with motivation, a person's internal values and personal norms can also be a motivating factor that affects his or her helping behaviour (Green and Webb, 2000: 301) and there is enough evidence that prosocial norms are the determinants of individual helping behaviour (Krebs, 1970). AHO was defined by Green and Webb (2000) as «the global and relatively enduring evaluations with regard to helping or assisting people». The third variable related to the present study is trust in the third sector. Since a great number of authors having a different point of views have made the definitions of trust, it is not possible to make a single definition covering the whole aspects of the concept. However, when these definitions are analysed, it is possible to suggest some important aspects concerning the third sector. Firstly, trust is the belief that one party will behave in a manner that results in positive outcomes of the other party (Anderson and Narus, 1990). Secondly, trust is the confidence that the other party is able to fulfil its obligations and position the exchange partner in mind as a partner you can rely on (Mohr and Spekman, 1994; Anderson and Weitz,1989) and lastly, a belief that the other party will act expectedly (Selnes,1998). As it could be well understood from the definitions above, trust plays a crucial role in kinds of relationships. Nonetheless, it is even more important for the donor-charity relationships because people cannot exactly trace the money they donate to these organizations or they cannot exactly know with whom they spend their time or effort for (Bekkers, 2003). Trust in the third sector in this paper refers to trust that COs in the sector will behave for the goodness of the people in society and the belief that COs will not abuse the donors or beneficiaries (Sargeant, 2004).The fourth and final variable that this study focuses on is attitudes toward charitable organizations (ACO). Individuals have various alternative ways to support the needy. Donating to $\mathrm{COs}$ is one of the ways of supporting the needy. However, the donation process does not take place in an alienated world. COs act as intermediaries in the donation process collecting resources from individuals who want to help and transfer these resources to beneficiaries (Bendapudi et al., 1996). Individuals are exposed to news to $\mathrm{CO}$ s quite frequently, share their opinions about charities with others and experience their own relationships with $\mathrm{COs}$ as donors or beneficiaries. Beyond doubt, these realities affect an individuals' general opinions about $\mathrm{CO}$ s and help them formulate their attitudes toward these organizations. One sort of attitude related to these organizations is ACO and Green and Webb (2000) defined ACO as the general and ongoing evaluations about the COs which help people in need. As previously cited, AHO is a factor that is associated with empathy and altruism (Green and Webb, 2000) and there are numerous studies regarding the relationship between these two variables and helping behaviour. The findings of these studies reveal that all of these variables are positively correlated with helping behaviour (e.g. Coke et al., 1978; Fultz et al., 1986; Einolf, 2008). However, prior research paid less attention to $\mathrm{AHO}$ and found that a more positive attitude toward helping others increases the likelihood of charitable giving both for time (Briggs et al., 2010) and money (Veludo-deOliveira et al., 2017). Regarding the importance of $\mathrm{AHO}$ and prior research, it is favourable to generate the following hypotheses:

$\mathrm{H}_{1}$ : Attitudes toward helping others have a positive direct influence on intention to give money to charitable organizations. 
$\mathrm{H}_{2}$ : Attitudes toward helping others have a positive direct influence on intention to give time to charitable organizations.

The individuals who prefer giving money to $\mathrm{CO}$ need to have a belief that these organizations are able to make this transaction well (Laidler-Kylander and Simonin, 2007). Consequently, positive attitude toward $\mathrm{CO}$ s is required for a successful charitable giving process (Hassan et al., 2018). Furthermore, the results of the research also indicate that there is a positive relationship between AHO and ACO (Ranganathan and Hanley, 2008; Briggs et al., 2010). Given the role played by COs and according to the findings of the related literature, it is anticipated that having a positive attitude toward helping others should have a positive direct influence on the attitudes toward COs:

$\mathrm{H}_{3}$ : Attitudes toward helping others have a positive direct influence on the attitudes toward charitable organizations.

There are controversial findings in the related literature about the relationship between attitudes and trust. While some studies have suggested that trust should be a predictor of attitudes toward a given object (e.g. Corbitt et al., 2003), other studies reported the opposite (See: Frewer et al., 2003; Chang and Wong, 2015). These contradictory results may be due to the absence of the boundaries between trust and attitude (Jones, 1996). In a recent study, the approach to this relationship was inspired by Festinger's (1957) theory of cognitive dissonance. According to this theory, individuals try to avoid discomfort caused by inconsistency among their beliefs, attitudes and behaviour. Hence, if an individual has positive attitudes toward a specific object, then he or she should generate positive beliefs about the given object not to feel discomfortable. Therefore, it is quite reasonable to expect that individuals' level of trust and attitudes toward a given object should overlap. Furthermore, there are clues that support this assumption. For example, Stanley et al. (2011) found that implicit race attitudes influence trustworthiness judgments. Particularly, the people who have a positive attitude toward some race tend to believe that the members of this racial group are trustworthy. Additionally, Kemp et al. (2014) found that people with more positive attitudes toward a brand have a higher level of trust in this brand. Therefore, it can be argued that individuals who have positive attitudes toward COs should have a higher level of trust in the third sector:

$\mathrm{H}_{4}$ : Attitudes toward charitable organizations have a positive direct influence on trust in the third sector.

The individuals regarding that $\mathrm{CO}$ s are not useful, managed improperly or not efficient are not intended to donate time or money to COs (Musick and Wilson, 2008: 104-105). Likewise, Sargeant and Lee (2004) found that a higher level of trust in COs results in a better relationship between the public and the third sector. In the following study (Sargeant et al., 2006), a positive relationship between trust and charitable behaviour was found. On the other hand, the findings of relatively recent studies also suggest that NPOs should have at least an adequate level of public trust in order to be supported by the individuals (Hager veHedberg, 2016; Alhidari et al., 2018). Briefly, without trust, it is hard for charities to build successful relationships with donors (Bryce, 2007) and convince them to donate time or money to COs. Therefore, we hypothesize the following hypotheses:

$\mathrm{H}_{5}$ : Trust in the third sector has a positive direct influence on intention to give money to charitable organizations.

$\mathrm{H}_{6}$ : Trust in the third sector has a positive direct influence on intention to give time to charitable organizations.

According to the given theories and results of the prior research regarding the relationship between attitudes toward COs or other highly correlated concepts on charitable giving intentions and the assumptions we made using their findings, we expect that in sequence, attitudes toward charitable organizations and trust in the third sector should mediate the influence of attitudes toward helping others on charitable giving intentions. Therefore, we propose the following hypotheses. 
$\mathrm{H}_{7 a}$ : Attitude toward helping others will indirectly influence individuals' intentions to donate money to charitable organizations casually linked multiple mediators of attitudes toward charitable organizations and trust in the third sector.

$\mathrm{H}_{7 \mathrm{~b}}$ : Attitude toward helping others will indirectly influence individuals' intentions to donate money to charitable organizations casually linked multiple mediators of attitudes toward charitable organizations and trust in the third sector.

Methodology and research methods. The population of this study has consisted of the individuals who are at the age of 18 or older and living in the region of Eastern Marmara. A convenience sample of 614 individuals participated in the research in a two-year period (August 2016 - August 2018) who live in the cities of Bursa, Sakarya and Kocaeli. In order to decrease the effect of common method bias on research data (Podsakoff et al., 2003), the respondents were first asked whether they could count the three of the COs operating in Turkey. After that, the respondents who failed to count three names were excluded from the sample. This method is an adapted version of a similar method used by Michel and Rieunier (2012) and it was believed to pre-eliminate the data which may have been derived from the respondents who were not acknowledged enough about charitable COs, which may have resulted in gathering biased responses and distracting the validity of the study. In total, $484(78,82 \%)$ filled questionnaire forms were reached using the only face to face method. However, after checking the negatively worded items that were prepared to detect the acquiescence response bias (Churchill, 1979) only $417(67,92 \%)$ of the forms were found to be reasonable for further analysis. According to Table 1 which shows the demographics of the respondents, an important part of data was gathered from female respondents $(58,4 \%)$ and more than half of the respondents have a high school degree $(51,1 \%)$. Additionally, the mean age of the respondents is 23,54 and most of the respondents are a student $(60,4 \%)$. The respondents were believed to have enough knowledge and the ability to understand the statements given in the questionnaire forms. In terms of population distribution, in sum, 5,911,612 people live in the cities of Bursa, Sakarya and Kocaeli. $50.19 \%$ of these people are male and $49.81 \%$ of them are female. The mean age of the population with an age of higher than 18 is 32,6 (TUIK,2019).

Table 1. Demographic Profile of the Respondents

\begin{tabular}{|c|c|c|c|}
\hline Variable & Name of the Category & $f$ & $\%$ \\
\hline \multirow[t]{2}{*}{ Gender } & Female & 241 & 58,4 \\
\hline & Male & 172 & 41,6 \\
\hline \multirow[t]{6}{*}{ Monthly Consumable Income } & 500 TL or less & 112 & 28,4 \\
\hline & $501 \mathrm{TL}-1000 \mathrm{TL}$ & 91 & 23,1 \\
\hline & $1001 \mathrm{TL}-1500 \mathrm{TL}$ & 55 & 14,0 \\
\hline & $1501 \mathrm{TL}-2000 \mathrm{TL}$ & 23 & 5,8 \\
\hline & $2001 \mathrm{TL}-2500 \mathrm{TL}$ & 25 & 6,3 \\
\hline & $2501 \mathrm{TL}$ and above & 88 & 22,3 \\
\hline \multirow[t]{4}{*}{ Education } & Primary School & 24 & 5,8 \\
\hline & High school & 211 & 51,1 \\
\hline & Graduate & 124 & 30,0 \\
\hline & Post Graduate & 54 & 13,1 \\
\hline \multirow[t]{4}{*}{ Occupation } & Public Organization & 72 & 17,3 \\
\hline & Private Organization & 69 & 16,5 \\
\hline & Student & 252 & 60,4 \\
\hline & Not Occupied & 18 & 4,3 \\
\hline Age (Mean) & \multicolumn{3}{|l|}{23,54} \\
\hline
\end{tabular}

Sources: calculated by the authors. 
Attitudes toward charitable organizations, attitudes toward helping others, trust in the third sector and intention to give time to charitable organizations and intention to give money to charitable organizations were chosen as the variables regarding the research. The research model showing the relationship based on the hypotheses is shown in Figure 1 the mentioned variables were measured by the scales adopted from the related studies conducted in the past. In order to measure the variable of attitudes toward charitable organizations, an adapted version of four items Likert type scale developed by Green and Webb (2000) was used.

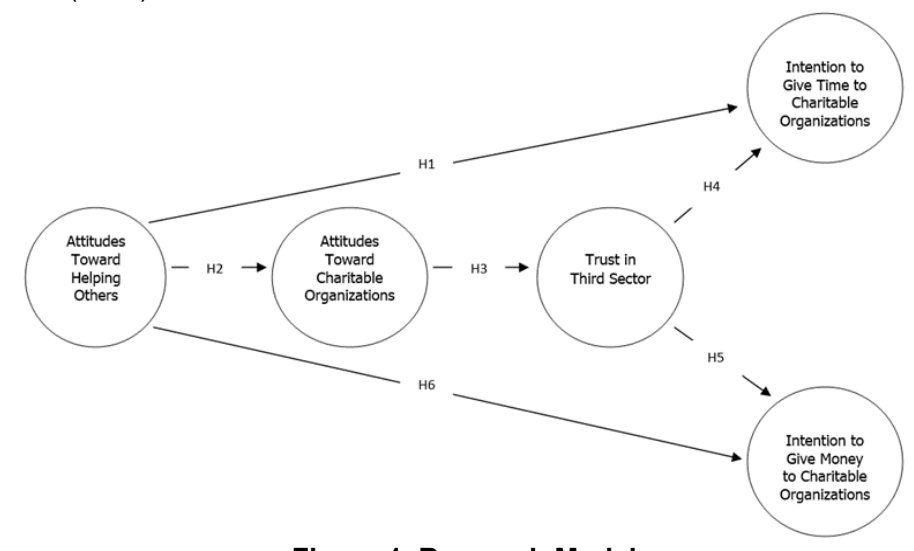

Figure 1. Research Model

Sources: developed by the authors.

Similarly, in order to measure the variable of attitudes toward helping others, an adapted version of four items Likert type scale developed by Green and Webb (2000) was administrated. Trust in the third sector was measured by an adapted version of a scale developed by Sargeant et al. (2006) which contained five Likert type items. Finally, the variables of intention to give time to COs and intention to give money to $\mathrm{CO}$ sere both measured by the adapted versions of four item Likert type scales developed by Ranganathan and Henley (2008). The literature suggests two common methods to test the statistical significance of mediation, which is the Sobel test and bootstrapping. Bootstrapping approach is relatively more powerful than the Sobel test for multiple reasons. Firstly, bootstrapping the indirect effects results in more statistical power than the Sobel test and it is more useful for multiple mediation analysis. Secondly, bootstrapping can be applied to small sample sizes without much concern and finally unlike Sobel test which requires normal distribution of the data, bootstrapping is free of the sampling distribution (Morera and Castro, 2013). Since the model represented in this study has multiple mediators and we have a relatively small sample, the bootstrapping approach was adopted while testing the mediation hypotheses.

Results. We used SmartPLS 3.2.6 (Ringle et al., 2005) in order to examine the measurement model consisting of reflective indicators. In the following phase, we performed analysis on items and constructs and tested whether the model has any reliability, convergent and discriminant validity issues. Previously, we checked the loadings of the indicators whether they are greater than 0.70 , a threshold score suggested by Hair et al. (2011). The results showed that only one indicator loaded into had a lower loading than suggested (ACO2: 0.693 ) and therefore it was excluded from the model. According to the results shown in Table 2, CR values of the constructs range from 0.852 (ACO) to 0.942 (IGMC). Hair et al. (2011) suggested that a CR value greater than 0.70 is adequate to satisfy internal consistency. Internal consistency was also evaluated based on Cronbach's Alfa scores and supported the values of CR. 
Table 2. Construct Reliability and Validity

\begin{tabular}{|c|c|c|c|c|c|}
\hline Name of the Construct & Item & Loadings & AVE & CR & $\begin{array}{l}\text { Cronbach's } \\
\text { Alfa }\end{array}$ \\
\hline \multirow{4}{*}{$\begin{array}{l}\text { Attitudes toward Charitable Organizations } \\
\text { (ACO) }\end{array}$} & $\mathrm{ACO} 1$ & 0.741 & 0.654 & 0.883 & 0.823 \\
\hline & ACO3 & 0.808 & & & \\
\hline & $\mathrm{ACO} 4$ & 0.863 & & & \\
\hline & ACO5 & 0.818 & & & \\
\hline \multirow[t]{4}{*}{ Attitudes toward Helping Others (AHO) } & $\mathrm{AHO1}$ & 0.788 & 0.724 & 0.913 & 0.873 \\
\hline & AHO2 & 0.874 & & & \\
\hline & $\mathrm{AHO3}$ & 0.887 & & & \\
\hline & AHO4 & 0.853 & & & \\
\hline \multirow{4}{*}{$\begin{array}{l}\text { Intention to Give Money to Charitable } \\
\text { Organizations } \\
\text { (IGMC) }\end{array}$} & IGMC1 & 0.920 & 0.801 & 0.941 & 0.917 \\
\hline & IGMC2 & 0.862 & & & \\
\hline & IGMC3 & 0.920 & & & \\
\hline & IGMC4 & 0.876 & & & \\
\hline \multirow{4}{*}{$\begin{array}{l}\text { Intention to Give Time to Charitable } \\
\text { Organizations } \\
\text { (IGTC) }\end{array}$} & IGTC1 & 0.849 & 0.761 & 0.927 & 0.897 \\
\hline & IGTC2 & 0.893 & & & \\
\hline & IGTC3 & 0.905 & & & \\
\hline & IGTC4 & 0.840 & & & \\
\hline \multirow{4}{*}{$\begin{array}{l}\text { Trust in the Third Sector } \\
\text { (TIS) }\end{array}$} & TIS1 & 0.868 & 0.690 & 0.899 & 0.850 \\
\hline & TIS2 & 0.743 & & & \\
\hline & TIS3 & 0.854 & & & \\
\hline & TIS5 & 0.853 & & & \\
\hline
\end{tabular}

Sources: calculated by the authors.

Additionally, in order to assess convergent validity, we checked average variance extracted (AVE) and the results indicated that none of the constructs has AVE score less than 0.50 while the scores range from 0.591 (ACO) to 0.942 (IGMC) which indicates that convergent validity criteria are matched. To sum up, the results show that the given model has no serious convergent validity issues and reliable enough to perform further analysis. In the next stage, we checked whether all items in the model had an adequate level of factor loading greater than 0.70 as suggested by Hair, Ringle and Starstedt (2011). Moreover, to ensure the discriminant validity, we first focused on cross-loadings so as to ensure that all indicators in the model highly correlated with only one latent variable. As expected earlier, TIS4 which was loaded into TIS with relatively high loading $(0.838)$ had also a loading score higher than 0.70 with ACO $(0.800)$. Therefore, this indicator was also excluded from the model to ensure the discriminant validity. Another method to assess discriminant validity is Fornell-Larcker Criterion (1981). According to this method, a construct should share a bigger part of its variance with its own indicators than with any of the constructs consisting the structural model. After comparing the AVE of each construct and the highest square correlation with constructs, we observed that each construct had a higher AVE value than the highest squared correlation with other constructs.

Table 3 shows that the square roots of AVEs are greater than the other values. After the elimination of the cross loaded factor TIS4 and matching the Fornell-Larcker Criterion (1981), we can assume that the structural model has no serious discriminant validity issues.

Table 4 shows the findings of the structural model suggest that $\mathrm{AHO}$ has a positive direct influence on ACO $(\beta=0.449, p=0.000)$ IGMC $(\beta=0.294 ; p=0.000)$ and IGTC $(\beta=0.226 ; p=0.000)$. ACO has a positive direct influence on TIS $(\beta=0,789 ; p=0,000)$. 
Table 3. Fornell-Larcker Criterion Analysis

\begin{tabular}{|l|c|c|c|c|c|}
\hline & ACO & AHO & IGMC & IGTC & TIS \\
\hline ACO & $\mathbf{0 . 8 0 9}$ & & & & \\
\hline AHO & 0.449 & $\mathbf{0 . 8 5 1}$ & & & \\
\hline IGMC & 0.599 & 0.446 & $\mathbf{0 . 8 9 5}$ & & \\
\hline IGTC & 0.449 & 0.322 & 0.633 & $\mathbf{0 . 8 7 2}$ & \\
\hline TIS & 0.789 & 0.371 & 0.518 & 0.341 & $\mathbf{0 . 8 3 1}$ \\
\hline
\end{tabular}

Sources: calculated by the authors.

Additionally, TIS has a positive direct influence on IGMC $(\beta=0.409, p=0.000)$ and IGTC $(\beta=0.226, p=$ 0.000 ) and ACO has a positive direct influence on TIS ( $\beta=0.789, p=0.000$ ). Hence, $\mathrm{H}_{1}, \mathrm{H}_{2}, \mathrm{H}_{3}, \mathrm{H}_{4}, \mathrm{H}_{5}$ and $\mathrm{H}_{6}$ hypotheses are supported as the model explains about $35 \%$ of the variance in IGMC and $11 \%$ of the variance in IGTC.

Table 4. Findings of the structural model (Direct Effects)

\begin{tabular}{|l|c|c|c|c|c|}
\hline \multicolumn{1}{|c|}{ Hypothesis } & Beta & $\begin{array}{c}\text { Standard } \\
\text { Deviation }\end{array}$ & T-Values & P Values & Decision \\
\hline $\mathrm{H}_{1}: \mathrm{AHO} \rightarrow \mathrm{IGTC}$ & $0.226^{*}$ & 0.048 & 4.668 & 0.000 & Supported \\
\hline $\mathrm{H}_{2}: \mathrm{AHO} \rightarrow \mathrm{ACO}$ & $0.449^{*}$ & 0.054 & 8.321 & 0.000 & Supported \\
\hline $\mathrm{H}_{3}: \mathrm{ACO} \rightarrow \mathrm{TIS}$ & $0.789^{*}$ & 0.024 & 32.197 & 0.000 & Supported \\
\hline $\mathrm{H}_{4}: \mathrm{TIS} \rightarrow \mathrm{IGTC}$ & $0.258^{*}$ & 0.059 & 4.381 & 0.000 & Supported \\
\hline $\mathrm{H}_{5}: \mathrm{TIS} \rightarrow \mathrm{IGMC}$ & $0.409^{*}$ & 0.055 & 7.408 & 0.000 & Supported \\
\hline $\mathrm{H}_{5}: \mathrm{AHO} \rightarrow \mid \mathrm{GMC}$ & $0.294^{*}$ & 0.053 & 5.605 & 0.000 & Supported \\
\hline
\end{tabular}

${ }^{*}$ Significant at the $\% 95$ confidence level

Sources: calculated by the authors.

As indicated earlier in the present study, we incorporated IGMC and IGTC as dependent variables. In terms of our model, we conducted the serial mediation analyses using SmartPLS 3.2.6 which is a software capable of allowing researchers to examine specific indirect effects and tests significance of the mediation using the bootstrap methodology in a confidence interval. We tested whether ACO and TIS sequentially mediate the influence of AHO on both IGTC and IGMC with bootstrapping methodology using 5000 sub-sample. If the confidence interval does not include zero, the mediation pathway is considered statistically significant (Pittinsky and Montoya, 2016). According to Table 5 which shows the results of the mediation analysis, there were significant total effects of AHO on IGMC $(\beta=0.499 ; t=$ 9.076; $p<0.000)$ and IGTC $(\beta=0.404 ; t=7.552 ; p<0.000)$.

Table 5. Specific Indirect Effects and Serial Mediation Analysis

\begin{tabular}{|l|c|c|c|c|c|c|}
\hline \multicolumn{1}{|c|}{ Specific Indirect Effects } & Beta & T-Values & P Values & $\mathbf{2 . 5 \%}$ & $\mathbf{9 7 . 5 \%}$ & Decision \\
\hline $\mathrm{ACO} \rightarrow \mathrm{TIS} \rightarrow I G M C$ & $0.323^{*}$ & 6.983 & 0.000 & 0.227 & 0.407 & \\
\hline $\mathrm{H}_{7 \mathrm{a}: \mathrm{AHO} \rightarrow \mathrm{ACO} \rightarrow \mathrm{TIS} \rightarrow \mathrm{IGMC}}$ & $0.145^{*}$ & 6.004 & 0.000 & 0.100 & 0.193 & Mediation \\
\hline $\mathrm{ACO} \rightarrow \mathrm{TIS} \rightarrow \mathrm{IGTC}$ & $0.203^{*}$ & 4.249 & 0.000 & 0.106 & 0.294 & \\
\hline $\mathrm{H}_{7 b} \mathrm{~A} \mathrm{~A} \mathrm{~A} \rightarrow \mathrm{ACO} \rightarrow \mathrm{TIS} \rightarrow I \mathrm{GTC}$ & $0.091^{*}$ & 3.866 & 0.000 & 0.047 & 0.139 & Mediation \\
\hline $\mathrm{AHO} \rightarrow \mathrm{ACO} \rightarrow \mathrm{TIS}$ & $0.354^{*}$ & 8.063 & 0.000 & 0.262 & 0.434 & \\
\hline
\end{tabular}

${ }^{*}$ Significant since the $\% 97.5 \mathrm{Cl}$ does not include zero

Sources: calculated by the authors.

After this, we tested whether the relationship between AHO and IGMC and IGTC was mediated by the sequential $\mathrm{ACO}$ to TIS. In line with the assumptions, there was an overall indirect effect of $\mathrm{AHO}$ on 
IGTC $(\beta=0.091,97.5 \% \mathrm{Cl}=0.047-0.139)$ and AHO on IGTC $(\beta=0.145,97.5 \% \mathrm{Cl}=0.047-0.139)$. Therefore, we accepted the $\mathrm{H}_{7 a}$ and $\mathrm{H}_{7 b}$ hypotheses. The results suggest that $\mathrm{AHO}$ and TIS mediate the relationship between $\mathrm{CGI}$ and $\mathrm{AHO}$ sequentially.

Table 6. Construct Cross-validated Redundancy

\begin{tabular}{|c|c|c|c|}
\hline Total & SSO & SSE & 1-SSE/SSO \\
\hline ACO & $1,668.000$ & $1,472.311$ & 0.117 \\
\hline AHO & $1,668.000$ & $1,668.000$ & \\
\hline IGMC & $1,251.000$ & 949.282 & 0.241 \\
\hline IGTC & $1,251.000$ & $1,097.422$ & 0.123 \\
\hline TIS & $1,668.000$ & $1,087,621$ & 0.348 \\
\hline
\end{tabular}

Sources: calculated by the authors.

This approach suggests that a Q2 (1-SSE/SSO) value of higher than zero shows that the indicators for the given construct are accurately predicted. According to Table 6 , the highest predictive relevance is TIS (0.348) and the lowest is ACO (0.117). Since all of the Q2 values are significantly larger than zero, it is verified that all variables in the model have adequate predictive relevance.

Conclusions. The main purpose of this study was to examine the serial mediating role of attitude toward charitable organizations and trust in the third sector in the relationship between attitude toward helping others and charitable giving intention. Accordingly, this paper was believed to make two important contributions to the related literature with two significant findings. The first important finding of the present study is that attitude toward charitable organizations and trust in the third sector has a serial mediating role in the relationship between attitude toward helping others and intention to give time (to volunteer) and intention to give money. The second important contribution of this paper is that attitude toward charitable organizations has a positive direct effect on trust in the third sector. In addition to these, the other major contribution is that this study has taken time donations into account in charitable behaviours while the previous studies had paid relatively less attention to the concept. This study has also some limitations like any other studies. The results of this study cannot be generalized. In addition to this, the present study focused on the mediating role of frequently studied organizational variables such as ACO and TIS. Hence, future research may explore other possible mediating variables such as brand image and brand attitude. Last but not least, it can be noted that our model in this study can be tested for a specific charitable organization. From the social marketing point of view, it is a two-way street between the organization and people at large On the one hand, practitioners need to focus on people's perception of their organization. It includes three points. Firstly, there should be an emotional attachment between the organization and the donor based on trust. Secondly, the organization should convince that the resources provided by the donors will be used efficiently and effectively. Lastly, donors should be persuaded that donations will be delivered to whom the donors intended. On the other hand, the points outlined above are necessary but not sufficient for generating a higher level of intention to donate. Because, although the variables which relate to intention to donate are important, the causal sequence of these variables is also important. It appears that increasing the level of attitudes toward helping others can result in generating a more positive perception about voluntary organizations. To simplify the results, marketing practitioners who work for voluntary organizations should focus on promoting people's attitudes toward helping others to generate better public trust which in turn could result in higher donations. There are a substantial number of studies examining the characteristics of the people who donate (Lee and Chang, 2007; Bekkers and Wiepking, 2011). However, there are hardly any studies examining the characteristics of people who abstain from donating. It is obvious that there is a gap in the literature in regard to the demographic and behavioural characteristic of these people. If their 
characteristics are known, it will be possible to design promotional policies to raise awareness in this group. To address this problem, there can be an umbrella charity organization that periodically conducts research and surveys the characteristics of the people who donate as well as who do not. That research will provide a valuable source of information about the people who are less willing to help.

Author Contributions. Conceptualization, V. G., and E. E.; data curation, V. G., and E. E.; formal analysis, V. G.; investigation, V.G., and E. E.; supervision, R. A., and K. A.; validation, V. G.; Visualization, V. G., and E. E.; Writing - original draft, V. G., and E. E.; Writing - review \& editing, V. G., E. E., R. A., K. A.

\section{References}

Alhidari, I. S., Veludo-de-Oliveira, T. M., Yousafzai, S. Y., and Yani-de-Soriano, M. (2018). Modelling the Effect of Multidimensional Trust on Individual Monetary Donations to Charitable Organizations. Nonprofit and Voluntary Sector Quarterly, 47(3), 623-644. DOI: 10.1177/0899764017753559

Anderson, J., and Narus, J. (1990). A Model of Distributor Firm and Manufacturer Firm Working Partnerships. Journal of Marketing, 54(1), 42-58. DOI:10.2307/1252172

Anderson, E., and Weitz, B. (1989). Determinants of Continuity in Conventional Industrial Channel Dyads. Marketing Science, 8(4), 310-323.

Banks, J. O., and Raciti, M. M. (2018). Perceived Fear, Empathy and Financial Donations to Charitable Services. The Service Industries Journal, 38:5-6, 343-359. DOI: 10.1080/02642069.2017.1402888

Batson, C. D., Batson, J. G., Slingsby, J. K., Harrell, K. L., Peekna, H. M., and Todd, R. M. (1991). Empathic Joy and the Empathy-Altruism Hypothesis. Journal of Personality and Social Psychology, 61, 413-426.

Bekkers, R. (2003). Trust, Accreditation, and Philanthropy in the Netherlands. Nonprofit and Voluntary Sector Quarterly, 32(4), 596-615. DOI: 10.1177/0899764003258102

Bekkers, R., \& Wiepking, P. (2011). A Literature Review of Empirical Studies of Philanthropy: Eight Mechanisms That Drive Charitable Giving. Nonprofit and Voluntary Sector Quarterly, 40(5), 924-973. https://DOI.org/10.1177/0899764010380927

Bendapudi, N., Singh, S. N., and Bendapudi, V. (1996). Enhancing Helping Behavior: An Integrative Framework for Promotion Planning. Journal of Marketing, 60(3), 33-49. DOI: 10.2307/1251840

Blau, P. M. (1964). Exchange and Power in Social Life. New York: John Wiley.

Briggs, E., Peterson, M., and Gregory, G. (2010). Toward a Better Understanding of Volunteering for Nonprofit Organizations:

Explaining Volunteers' Pro-Social Attitudes. Journal of Macromarketing, 30(1), 61-76. DOI: 10.1177/0276146709352220

Bryce, H. J. (2007). The Public's Trust in Nonprofit Organizations: The Role of Relationship Marketing and Management. California Management Review, 49(4), 112-131. DOI: 2307/41166408

CAF. (2016). CAF World Giving Index 2016 The world's leading study of generosity. Retrieved from https://www.cafonline.org/docs/default-source/about-us-publications/1950a_wgi_2016_report_web_v2_241016.pdf

CAF. (2018). CAF World Giving Index 2018 A global view of giving trends. Retrieved from

https://www.cafonline.org/docs/default-source/about-us-publications/caf_wgi2018_report_webnopw_2379a_26 1018.pdf

Chang, S. L., and Wong, C. C. (2015). Attitude as a Predictor of Trust in Food Safety. A Study of Malaysian Chinese College

Students. Universal Journal of Psychology, 3(6), 160-164. DOI: 10.13189/ujp.2015.030602

Churchill, G. (1979). A Paradigm for Developing Better Measures of Marketing Constructs. Journal of Marketing Research, 16(1), 64-73. DOI:10.2307/3150876

Cialdini, R. B., Darby, B. L., and Vincent, J. E. (1973). Transgression and Altruism: A Case for Hedonism. Journal of Experimental Social Psychology, 9(6), 502-516.DOI:10.1016/0022-1031(73)90031-0

Coke, J. S., Batson, C. D., and McDavis, K. (1978). Empathic Mediation of Helping: A Two-Stage Model. Journal of Personality and Social Psychology, 36(7), 752-766. DOI: 10.1037/0022-3514.36.7.752

Corbitt, B. J., Thanasankit, T., and Yi, H. (2003). Trust and E-Commerce: A Study of Consumer Perceptions. Electronic Commerce Research and Applications, 2, 203-215. DOI: 10.1016/S1567-4223(03)00024-3

Einolf, C. J. (2008). Empathic Concern and ProsocialBehaviors: A Test of Experimental Results Using Survey Data. Social Science Research, 37(4), 1267-1279. DOI: 10.1016/j.ssresearch.2007.06.003

Festinger, L. (1957). A Theory of Cognitive Dissonance. Stanford, CA: Stanford University Press.

Fornell, C., and Larcker, D. (1981). Evaluating Structural Equation Models with Unobservable Variables and Measurement Error. Journal of Marketing Research, 18(1), 39-50. DOI:10.2307/3151312

Frewer, L. J., Scholderer, J. and Bredahl, L. (2003). Communicating about the Risks and Benefits of Genetically Modified

Foods. The Mediating Role of Trust. Risk Analysis, 23(6), 1117-1133. DOI: 10.1111/j.0272-4332.2003.00385.x.

Fultz, J., Batson, C. D., Fortenbach, V. A., McCarthy, P. M., and Varney, L. L. (1986). Social Evaluation and the EmpathyAltruism Hypothesis. Journal of Personality and Social Psychology, 50(4), 761-769. DOI: 10.1037/0022-3514.50.4.761

Hager M. A. and Hedberg E. C. (2016) Institutional Trust, Sector Confidence, and Charitable Giving. Journal of Nonprofit\&

Public Sector Marketing, 28(2), 164-184, DOI: 10.1080/10495142.2015.1011508 
Hair, J. F., Hult, G. T. M., Ringle, C. M., Sarstedt, M., and Thiele, K. O. (2017). Mirror, Mirror on the Wall: A Comparative Evaluation of Composite-Based Structural Equation Modeling Methods. Journal of the Academy of Marketing Science, 45(5), 616632. DOI: $10.1007 / \mathrm{s} 11747-017-0517-\mathrm{x}$

Hair J. F., Ringle, C. M., and Sarstedt, M. (2011). PLS-SEM: Indeed a Silver Bullet. Journal of Marketing Theory and Practice, 19(2), 139-152, DOI: 10.2753/MTP1069-6679190202

Hassan, S. H., Masron, T. A., Mohamed, N., and Thurasamy, T. (2018). Antecedents of Trust towards the Attitude of Charitable Organisation in Monetary Philanthropic Donation among Generation-Y. Asian Academy of Management Journal, 23(1), 53-78. DOI: 10.21315/aamj2018.23.1.3

Hinde, R.A., and Groebel, J. (1991). Cooperation and ProsocialBehavior. New York: Cambridge University Press.

Ipsos MORI. (2016). Public Trust and Confidence in Charities. Retrieved from https://assets.publishing.service.gov.uk/government/uploads/system/uploads/attachment_data/file/532109/Public_trust_and_confid ence_in_charities.pdf

Janus, E., and Misiorek, A. (2018). Why do People Help Each Other? Motivations of Volunteers Who Assisted Persons with Disabilities During World Youth Day. Journal of Religion and Health, 1(8), DOI: 10.1007/s10943-018-0625-z Jones, K. (1996). Trust as an Affective Attitude. Ethics, 107(1), 4-25. Retrieved from http://www.jstor.org/stable/2382241 Kandaurova M., and Lee S. H. M. (2018). The Effects of Virtual Reality (VR) on Charitable Giving: The Role of Empathy, Guilt, Responsibility, and Social Exclusion. Journal of Business Research, 2018, ISSN 0148-2963, DOI: 10.1016/j.jbusres.2018.10.027. Kemp, E., Jillapalli, R., and Becerra, E. (2014). Healthcare Branding: Developing Emotionally Based Consumer Brand Relationships. Journal of Services Marketing, 28(2), 126-137. DOI: 10.1108/JSM-08-2012-0157 Krebs, D. L. (1970). Altruism: An Examination of the Concept and a Review of the Literature. Psychological Bulletin, 73(4), 258-302. DOI:10.1037/h0028987

Laidler-Kylander, N., and Simonin, B. (2009). How International Nonprofits Build Brand Equity. International Journal of Nonprofit and Voluntary Sector Marketing, 14(1), 57-69. DOI: 10.1002/nvsm.353

Lee, Y., and Chang, C. (2007). Who Gives What to Charity? Characteristics Affecting Donation Behavior. Social Behavior and Personality: An international journal, 35, 1173-1180.

Matenge, T. M. (2015). How Much to Donate: The Effect of Donors' Nature on Attitude toward Donations and Donation Value. International Journal of Economics, Commerce and Management, 3(1), 1-12.

Michel, G., and Rieunier, S. (2012). Nonprofit Brand Image and Typicality Influences on Charitable Giving. Journal of Business Research, 65(5), 701-707.

Mohr, J., and Spekman, R. (1994). Characteristics of Partnership Success: Partnership Attributes, Communication Behavior, and Conflict Resolution Techniques. Strategic Management Journal, 15(2), 135-152.

Morera, O. F., and Castro, F. G. (2013). Important Considerations in Conducting Statistical Mediation Analyses. American Journal of Public Health, 103(3), 394-396. DOI:10.2105/AJPH.2012.301047 Musick, M. A., and Wilson, J. (2008). Volunteers: A Social Profile. Indianapolis: Indiana University Press.

Veludo-de-Oliveira, T. M., Alhaidari, I. S., Yani-de-Soriano, M., and Yousafzai, S. Y. (2017). Comparing the Explanatory and Predictive Power of Intention-Based Theories of Personal Monetary Donation to Charitable Organizations. Voluntas: International Journal of Voluntary and Nonprofit Organizations, 28(2), 571-593. DOI: 10.1007/s11266-016-9690-7

Pãcesilã, M., and Ciocoiu, C. N. (2017). Systematic Literature Review on Eco-Innovation Determinants. Management Research and Practice, 9(3), 30-44.

Pittinsky, T. L., and Montoya, R. M. (2016). Empathic Joy in Positive Intergroup Relations. Journal of Social Issues, 72(3), 511-523. DOI:10.1111/josi.12179

Podsakoff, P. M., MacKenzie, S. B., Lee, J.-Y., and Podsakoff, N. P. (2003). Common Method Biases in Behavioral Research: A Critical Review of the Literature and Recommended Remedies. Journal of Applied Psychology, 88(5), 879-903. DOI: 10.1037/0021-9010.88.5.879

Ranganathan, S. K. and Henley, W. H. (2008). Determinants of Charitable Donation Intentions: A Structural Equation Model. International Journal of Nonprofit Voluntary Sector Marketing, 13, 1-11. DOI:10.1002/nvsm.297

Ringle, C. M., Wende, S., and Becker, J.-M. (2015). SmartPLS 3. Bonningstedt: SmartPLS. Retrieved from http://www.smartpls.com

Sargeant, A., and Lee, S. (2004). Donor Trust and Relationship Commitment in the U.K. Charity Sector: The Impact on Behavior. Nonprofit and Voluntary Sector Quarterly, 33(2), 185-202. DOI: 10.1177/0899764004263321

Sargeant, A., Ford, J. B., and West, D. C. (2006). Perceptual Determinants of NonprofitGiving Behavior. Journal of Business Research, 59, 155-165. DOI: 10.1016/j.jbusres.2005.04.006 Sargeant, A. (2009). Marketing Management for Nonprofit Organizations (3rd ed.). USA: Oxford University Press. Selnes, F. (1998). Antecedents and Consequences of Trust and Satisfaction in Buyer-Seller Relationships. European Journal of Marketing, 32(3/4), 305-322. DOI: 10.1108/03090569810204580

Smith, K. D., Keating, J. P., and Stotland, E. (1989). Altruism Reconsidered: The Effect of Denying Feedback on a Victim's Status to Empathic Witnesses. Journal of Personality and Social Psychology, 57(4), 641-650. DOI: 10.1037/0022-3514.57.4.641 Stanley, D. A., Sokol-Hessner, P., Banaji, M. R., and Phelps, E. A. (2011). Implicit Race Attitudes Predict Trustworthiness Judgments and Economic Trust Decisions. PNAS Proceedings of the National Academy of Sciences of the United States of America, 108, 7710-7775. DOI:10.1073/pnas.1014345108 
Turkish Republic Ministry of Interior Department of Association. (2019). Number of Active Associations. Retrieved from https://www.dernekler.gov.tr/

Triandis, H.C. (1980). Values, Attitudes, and Interpersonal Behavior. Nebraska Symposium on Motivation, University of Nebraska Press, Lincoln.

TUIK (Turkey Statistics Institution). (2019). Retrieved fromhttps://www.turkiye.gov.tr/turkiye-istatistik-kurumu-baskanligi-tuik

TUSEV. (2016a). Turkiye'de Bireysel Bagışçllik Ve Hayırseverlik Ozel Bulten. Retrieved from

https://www.tusev.org.tr/usrfiles/images/belgeler/TUSEV_bb_infografik_posterToplu_21.10.16..pdf

TUSEV. (2016b). Turkiye'de Bireysel Bagış̧̧וlık Ve Hayırseverlik Ozel Bulten. Retrieved from https://www.tusev.org.tr/usrfiles/images/belgeler/Turkiye'de_Bireysel_Bagiscilik_ve_Hayirseverlik_Ozel_Bulten.pdf

Varhaert, A. G., and den Poel, D. V. (2011). Empathy as Added Value in Predicting Donation Behavior. Journal of Business Research. 64, 1288-295. DOI: 10.1016/j.jbusres.2010.12.024

Warshaw, P. R., and Davis, F. D. (1984). Self-Understanding and the Accuracy of Behavioral Expectations. Personality and Social Psychology Bulletin, 10(1), 111-118. DOI: 10.1177/0146167284101013

Webb, D. J., Green, C. L., and Brashear, T. G. (2000) Development and Validation of Scales to Measures Attitudes Influencing Monetary Donations to Charitable Organizations. Journal of the Academy of Marketing Science, 28(2), 299-309.

Yang, A., Urminsky, O., and Hsee, C. K. (2015). Eager to Help yet Reluctant to Give: How Pro-Social Effort and Pro-Social Choices Diverge (Working paper). University of Chicago, Chicago, IL

Волкан Гоктас, Університет Сакар'я (Туреччина);

Умре Ерол, Університет Сакар'я (Туреччина);

Ремзі Алтунісік, Ph.D., профресор, Університет Сакар'я (Туреччина);

Кадір Ардік, Ph.D., профессор, Університет Сакар'я (Туреччина).

Соціальний маркетинг у благодійних організаціях: модель послідовного посередництва

Благодійні організації відграють значну роль у сучасному суспільстві на противагу органам державного управління чи суб'єктам підприємницької діяльності. Місія благодійних організацій $\epsilon$ широкомасштабною та починається від забезпечення продуктами харчування жертв стихійних лих до надання притулку біженцям, які рятуються від воєнних конфрліктів та політичних переслідувань. Однак, для досягнення вищезазначених цілей благодійні організації потребують підтримки фозичних осіб у вигляді фрінансових та часових ресурсів (волонтерська робота). Автори зазначають, що благодійні організації виступають у ролі посередницького апарату та передають ресурси від вищого (які прагнуть допомогти) до малозабезпеченого класу суспільства. Таким чином, визначення ролі пожертв фізичних осіб для благодійних організацій з маркетингової точки зору $є$ актуальним. У статті проаналізовано сприйняття ролі та ставлення до благодійних організацій з боку суспільства. Авторами зазначено, що низка фракторів поведінки та сприйняття впливають на: благодійні наміри фрізичних осіб (включаючи їх ставлення до таких організацій); готовність допомагати іншим та довіру до неурядових організацій. При цьому авторами визначено, що у раніше проведених дослідженнях науковців встановлено взаємозв'язок між вищезазначеними змінними. Однак, у даних роботах взаємозв'язок між визначеними змінними та благодійними намірами досліджено окремо. Таким чином, автори приходять до висновку, що наразі незрозуміло, яким чином фрактори поведінки та сприйняття пов'язані між собою $і$ як вони впливають на благодійні наміри. Головною метою статті є перевірка послідовної посередницької моделі при оцінці ставлення до благодійних організацій та довіри до неурядових організацій у взаємозв'язку між ставленням до допомоги іншим та благодійними намірами. У зв'язку з иим, авторами представлено послідовну посередницьку модель, яка демонструє взаємозв'язок між змінними, вихідні данні для якої були сформовані на основі аналізу даних репрезентативної вибірки 147 респондентів, які проживають у регіоні Мармара, Туреччина. Результати проведеного дослідження свідчать про те, що ставлення до допомоги іншим має позитивний непрямий ефект як на наміри витрачати власний час (волонтерство), так і на наміри фрінансувати діяльність благодійних та неурядових організацій. Також авторами відмічено, що довіра до неурядових організацій має позитивний прямий ефект на наміри присвятити час та наміри фрінансувати їх фрункціонування.

Ключові слова: благодійна організація, допомога, маркетинг, довіра, благодійність, намір, філантропія.

Manuscript received: 20.03.2019.

(C) The author(s) 2019. This article is published with open access at Sumy State University. 